\title{
Studies on the Oxidizing Properties of Some Tellurinic Acid Anhydrides
}

\author{
JITENDER K. NARWAL ${ }^{\mathrm{a}}$, SAPANA GARG ${ }^{\mathrm{b}}$ and K. K. VERMA ${ }^{\mathrm{a}^{*}}$ \\ a JVMGRR College, Charkhi Dadri, Haryana, India \\ ${ }^{\mathrm{b}}$ Department of Chemistry, M.D. University, Rohtak-124001, India \\ vermakk123@rediffmail.com
}

Received 3 January 2013 / Accepted 14 February 2013

\begin{abstract}
Hydroxyphenyl tellurinic acid anhydride and 3-methyl-4-hydroxyphenyl tellurinic acid anhydride have been sythesized by alkaline hydrolysis of corresponding hydroxyaryl tellurium trichloride which in turn were obtained by the reactions of $\mathrm{TeCl}_{4}$ with phenol and $o$-cresol, respectively. These arene tellurinic acid anhydrides have been investigated as oxidizing reagents in the conversion of benzoin to benzil, 4-methoxy and 4-nitrobenzylalcohol to corresponding benzaldehydes, thiophenol to diphenyl disulphide, triphenylphosphine to triphenylphosphine oxide and hydroquinone to $p$-benzoquinone. The oxidizing property was found to be more in case of 3-methyl-4-hydroxyphenyl tellurinic acid anhydride as compared to $p$-hydroxyphenyl tellurinic acid anhydride.
\end{abstract}

Keywords: p-Hydroxyphenyl tellurinic acid anhydride, 3-Methyl-4-hydroxyphenyl tellurinic acid anhydride, Oxidizing properties

\section{Introduction}

Organotellurinic acid anhydrides have been known since many years ago, their chemical properties have been little investigated ${ }^{1}$. They are expected to have a potential oxidizing ability like organotelluroxides ${ }^{2}$ and tellurones ${ }^{3}$ due to their similar labile Te-O bonds. Barton et al. reported ${ }^{4}$ that aryl tellurinic acid anhydrides were oxidizing agents towards thiol, hydroquinones etc. These reports prompted us to report our independent study on the reactivity of organotellurinic acid anhydrides which is similar in many respect to that of the corresponding diaryl telluroxides and tellurones. Arenetellurinic acid anhydrides have recently been used as mild and selective oxidizing agents ${ }^{5,6}$.

\section{Experimental}

Melting point were determined in open capillary tube and are uncorrected. The IR spectra were recorded in $\mathrm{KBr}$ on F.T.I.R. Spectrometer Model RZX (Perkin Elmer) at SAIF, Panjab University, Chandigarh. The ${ }^{1} \mathrm{H}$ NMR were recorded in $\mathrm{CDCl}_{3}$ on FT-NMR Cryomagnet Spectrometer $400 \mathrm{MHz}$ (Bruker) using TMS as an internal standard. The purity of the compounds was checked by TLC using Silica gel-G (Merck). Column chromatography was 
performed on Silica gel (Merck, 60-120 mesh). Solvents for chromatography were distilled before use. The products were also characterized by comparison of their melting point with literature values.

\section{Preparation of organotellurinic acid anhydrides}

p-Hydroxyphenyl and 3-methyl-4-hydroxy phenyl tellurium (IV) trichlorides were obtained by the reaction of $\mathrm{TeCl}_{4}$ with phenol and $o$-cresol, respectively ${ }^{7-9}$. These trichlorides upon basic hydrolysis gave corresponding organotellurinic acid anhydrides.

\section{General experimental procedure for the oxidation reactions}

All the reactions were performed at reflux or room temperature under nitrogen atmosphere in toluene or acetic acid in presence of arene tellurinic acid anhydrides. The reaction was continued till completion of the reaction, as monitored by TLC. After the completion of the reaction, the contents were filtered and evaporation of filtrate followed by chromatographic separation $\left(\mathrm{SiO}_{2}\right.$, hexane / toluene (1:1)) from a small amount of diarylditelluride gave the product. All the products were identified by comparison with physical and spectral data.

\section{Benzil}

IR $\left(\mathrm{KBr}, \mathrm{cm}^{-1}\right): 1675(\mathrm{C}=\mathrm{O}),{ }^{1} \mathrm{H}$ NMR $\left(\mathrm{CDCl}_{3}, \delta \mathrm{ppm}\right): 7.8$ (m, 6H), 8.0 (m, 4h), m.p. $94-95{ }^{\circ} \mathrm{C}$ (lit ${ }^{10}$. m.p. $95^{\circ} \mathrm{C}$ ).

\section{p-Methoxybenzaldehyde}

IR $\left(\mathrm{KBr}, \mathrm{cm}^{-1}\right)$ : $1665(\mathrm{C}=\mathrm{O}), 1240(\mathrm{C}-\mathrm{O}-\mathrm{C}),{ }^{1} \mathrm{H}$ NMR $\left(\mathrm{CDCl}_{3}, \delta \mathrm{ppm}\right): 3.85$ (s, 3H), 6.98 (d, 2h), 9.86 (s, 1H), m.p. $245-247^{\circ} \mathrm{C}$ (lit ${ }^{11}$. m.p. $\left.246{ }^{\circ} \mathrm{C}\right)$.

\section{p-Nitrobenzaldehyde}

IR $\left(\mathrm{KBr}, \mathrm{cm}^{-1}\right): 1680(\mathrm{C}=\mathrm{O}), 1535\left(\mathrm{NO}_{2}\right),{ }^{1} \mathrm{H}$ NMR $\left(\mathrm{CDCl}_{3}, \delta \mathrm{ppm}\right): 8.1(\mathrm{~d}, 2 \mathrm{H}), 8.39$ (d, 2H), 10.1 (s, 1H), m.p.105-107 ${ }^{\circ} \mathrm{C}$ (lit ${ }^{12}$. m.p. $\left.106^{\circ} \mathrm{C}\right)$.

\section{Diphenyldisulphide}

IR $\left(\mathrm{KBr}, \mathrm{cm}^{-1}\right): 3055(\mathrm{Ar}-\mathrm{C}-\mathrm{H}), 1574(\mathrm{C}=\mathrm{C}), 826(\mathrm{C}-\mathrm{S}),{ }^{1} \mathrm{H}$ NMR $\left(\mathrm{CDCl}_{3}, \delta \mathrm{ppm}\right): 7.47-$ 7.24 (m, 10H), m.p. $72-74{ }^{\circ} \mathrm{C}\left(\right.$ lit ${ }^{13}$. m.p. $\left.73{ }^{\circ} \mathrm{C}\right)$.

\section{Triphenylphosphine oxide}

IR $\left(\mathrm{KBr}, \mathrm{cm}^{-1}\right): 3050(\mathrm{Ar}-\mathrm{C}-\mathrm{H}), 1436(\mathrm{P}=\mathrm{O}), 1189$ (P - Ar), ${ }^{1} \mathrm{H}$ NMR $\left(\mathrm{CDCl}_{3}, \delta \mathrm{ppm}\right): 7.71$ $(\mathrm{m}, 6 \mathrm{H}), 7.64-7.27$ (m, 9H), m.p. $154-156^{\circ} \mathrm{C}\left(\right.$ lit $^{14}$. m.p. $\left.156^{\circ} \mathrm{C}\right)$.

\section{p-Benzoquinone}

IR $\left(\mathrm{KBr}, \mathrm{cm}^{-1}\right): 1652(\mathrm{C}=\mathrm{O}),{ }^{1} \mathrm{H}$ NMR $\left(\mathrm{CDCl}_{3}, \delta \mathrm{ppm}\right): 6.76(\mathrm{~s}, 4 \mathrm{H})$, m.p. $113-115{ }^{\circ} \mathrm{C}\left(\mathrm{lit}^{15}\right.$. m.p. $\left.115^{\circ} \mathrm{C}\right)$.

\section{Results and Discussion}

Phenol and $o$-cresol appear to undergo Friedal-Crafts type condensation reaction with tellurium tetrachloride whereby the $\mathrm{TeCl}_{3}{ }^{+}$unit attacks a position para to a hydroxyl group in the aromatic ring. The formation of hydroxyaryltellurium(IV) trichlorides can be represented as

$$
\begin{gathered}
\mathrm{TeCl}_{4}+\mathrm{R}-\mathrm{H} \longrightarrow \mathrm{RTeCl}_{3}+\mathrm{HCl} \\
(\mathrm{R}-\mathrm{H}=\text { phenol, } o \text {-cresol })
\end{gathered}
$$


These hydroxyaryltellurium(IV) trichlorides upon alkaline hydrolysis yield the corresponding tellurinic acids:

$$
\mathrm{RTeCl}_{3}+3 \mathrm{NaOH} \longrightarrow \mathrm{R} \mathrm{Te}(\mathrm{O}) \mathrm{OH}+3 \mathrm{NaCl}+\mathrm{H}_{2} \mathrm{O}
$$

These tellurinic acids, upon dehydration give the tellurinic acid anhydrides.

$$
2 \mathrm{RTe}(\mathrm{O}) \mathrm{OH} \underset{\mathrm{ATeO}}{\longrightarrow})_{2} \mathrm{O}+\mathrm{H}_{2} \mathrm{O}
$$

These readily accessible arenetellurinic anhydrides i.e. $p$-hydroxyphenyltellurinic and 3methyl-4-hydroxyphenyltellurunic anhydrides have been investigated for their oxidizing properties towards six organic substrates viz. benzoin, 4-methoxybenzyl alcohol, 4-nitrobenzylalcohol, thiophenol, triphenylphosphine and hydroquinone. The oxidized products, their yields and reaction conditions are compiled in Tables 1 and 2. These hydroxyaryltellurinic anhydrides should exhibit a certain degree of basic character by virtue of polar nature of tellurium-oxygen bonds.<smiles></smiles>

Table 1. Oxidative Reactions with $p$-Hydroxyphenyl Tellurinic Anhydride

S.No Solvent Temp Time Reflux


Table 2. Oxidative Reactions with 3-Methyl-4-Hydroxyphenyl Tellurinic Anhydride

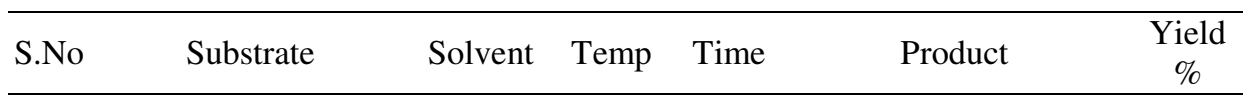

1.<smiles>O=C(c1ccccc1)C(O)c1ccccc1</smiles>
Toluene Reflux

2.<smiles>COc1ccc(CO)cc1</smiles>
Toluene Reflux $17 \mathrm{~h}$

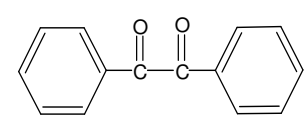

90

3.<smiles>O=[N+]([O-])c1ccc(CO)cc1</smiles>

Toluene Reflux

$18 \mathrm{~h}$<smiles>O=Cc1ccc(C=O)cc1</smiles><smiles>O=Cc1ccc([N+](=O)[O-])cc1</smiles>

4.<smiles>Sc1ccccc1</smiles>

Acetic acid<smiles></smiles>
30
$\min$<smiles>c1ccc(SSc2ccccc2)cc1</smiles>
85 $\mathrm{CH}_{2} \mathrm{Cl}_{2}$ r.t. $18 \mathrm{~h}$<smiles>O=P(c1ccccc1)(c1ccccc1)c1ccccc1</smiles>

Acetic acid $\begin{array}{cc}\text { r.t. } \quad & 30 \\ & \min \end{array}$

The oxidizing property of these anhydrides is by virtue of transfer of oxygen to the organic substrate and subsequently reduction to the ditellurides, $\mathrm{R}_{2} \mathrm{Te}_{2}$. It may be mentioned that in some cases, a little reduction to tellurium powder was also observed.

It has been observed that oxidizing property is more in case of 3-methyl-4hydroxyphenyl tellurinic acid anhydride as compared to $p$-hydroxyphenyl tellurinic acid anhydride. Also a comparison of oxidizing property of these anhydrides with those of corresponding telluroxides, show these acid anhydrides to be weaker oxidizing agents than the respective telluroxides.

\section{Conclusion}

p-Hydroxyphenyl and 3-methyl-4-hydroxyphenyl tellurinic anhydrides have been obtained by alkaline hydrolysis of corresponding hydroxyaryltellurium (IV) trichlorides, which in turn were obtained by direct reactions of tellurium tetrachloride with phenol and $o$-cresol, respectively.

These two tellurinic acid anhydrides have been investigated for their oxidizing property towards six organic substrates. They oxidize benzoin to benzil, 4-methoxy and 4-nitrobenzyl 
alcohol to corresponding benzaldehydes, thiophenol to diphenyl disulphide, triphenylphosphine to triphenylphosphine oxide and hydroquinone to $p$-benzoquinone. It has been observed that 3-methyl-4-hydroxyphenyl tellurinic anhydride is a better oxidizing agent than $p$-hydroxyphenyl tellurinic anhydride in these reactions. Also, the tellurinic anhydrides in general, are poor oxidizing reagents compared to the corresponding telluroxides.

\section{Acknowledgement}

The authors are thankful to the Head, SAIF, Panjab University, Chandigarh, for providing IR and ${ }^{1} \mathrm{H}$ NMR spectra.

\section{References}

1. Vicentini G, Giesbrecht E and Pitombo L R M, Chem Ber., 1959, 92, 40; Thavornynuntikaran P and Mcwhinnie W R, J Organomet Chem., 1973, 50, 135.

2. a) Barton D H R, Ley S V and Meerholz C A, J Chem Soc Chem Commun., 1979, 775-777; b) Ley S V, Meerholz C A and Barton D H R, Tetrahedron Lett., 1980, 21, 1785, Tetrahedron, 1981, 37(1). 1, 213-223.

3. Engman L and Cava M P, J Chem Soc Chem Commun., 1982, 164.

4. Barton D H R, Finet J-P and Thomas M, Tetrahedron, 1986, 42, 2319-2324.

5. Sasaki K, Aso Y, Otsubo T and Ogura F, Organotelluriums Part VII, Part VI, Chem Lett., 1986, 15(6), 977-978.

6. Hu N X, Aso Y, Otsubo T and Ogura F, Phosphorus Sulfur, 1988, 38(1-2), 177-189.

7. Khandelwal B L, Kumar K and Berry F J, Inorg Chim Acta, 1981, 47, 135-137.

8. Reichel L and Kirschbaum E, Ann Chem., 1936, 523, 211.

9. Khandelwal B L, Kumar K and Raina K, Synth React Inorg Met Org Chem., 1981, 11, 65-78.

10. $\quad$ Li J T, Liu X R and Wang W F, Ultrasonics Sonochemistry, 2009, 16(3), 331-333.

11. Chavan S P, Soni P B, Kale R R and Pasupathy K, Synth Commun., 2003, 33(6), 879-883.

12. Hojo K and Mukaiyama T, Chem Lett., 1978, 7(4), 369-372.

13. Karami B, Montazerozohori M and Habibi M H, Molecules, 2005, 10(10), 1358-1363.

14. Hu N X, Aso Y, Otsubo T and Ogura F, Chem Lett., 1985, 14, 603.

15. Yang T K and Shen C Y, 1,4-benzoquinone in Encyclopedia of Reagents for Organic Synthesis, J Wiley and Sons, New York, 2004. 